\title{
Population dynamic and fisheries management of Eeuropen sea bass, Dicentrarchus labrax (f. Moronidae) from Bardawil lagoon, North Sinai, Egypt
}

\section{Mohamed S. Ahmed}

Faculty of Environmental Agricultural Sciences, Suez Canal University, Egypt.

\begin{abstract}
Dopulation dynamic of European seabass, Dicentrarchus labrax was studied 1 from a small scale fishery of Bardawil lagoon. 1688 specimens ranged between 18.2 and $64.7 \mathrm{~cm}$ TL and 62 to $2823 \mathrm{~g}$ total weight, were collected from August, 2009 to November, 2010. The relationship between length and weight was estimated as $\mathrm{W}=0.014 \mathrm{~L}^{2.883}$. Age was determined using scales' reading technique for 586 individuals and the longevity of this species was found to be 6 years. Growth in length and weight at the end of each year was calculated. The growth parameters of the von Bertalanffy equation were calculated as $\mathrm{L}_{\infty}=70.82$ $\mathrm{cm}, \mathrm{K}=0.35 \mathrm{yr}^{-1}$ and $\mathrm{t}_{0}=-0.217 \mathrm{yr}$. The observed and predicted extreme lengths were 64.5 and $70.05 \mathrm{~cm}$, respectively. Total, natural and fishing mortality rates were $1.03 \mathrm{yr}^{-1}, 0.39 \mathrm{yr}^{-1}$ and $0.64 \mathrm{yr}^{-1}$, respectively. The current exploitation rate $(E=0.6229)$ indicated that the stock of seabass in Bardawil lagoon is heavily exploited. The length at first capture $L_{c}$ was estimated as $20.16 \mathrm{~cm}$. The maximum allowable limit of exploitation $\left(\mathrm{E}_{\max }\right)$ was 0.5 , while that at maximum economic yield was 0.42 . Based on these results, this important species may be in danger of severe declines in the near future where the stock was over-fished and small fish were unprotected by the current size regulation. Also, the results indicated that an increase of Lc would be associated with an increase in yields at the existing exploitation rate. Thus, for management purpose, the current exploitation rate must be reduced from 0.62 to $0.31(50 \%)$ or the present length at first capture (Lc) should be increased from 20.16 to $32 \mathrm{~cm}$ at the current the exploitation rate.
\end{abstract}

Key words: Population biology, Fisheries regulation, Dicentrarchus labrax, Bardawil lagoon, Egypt.

\section{INTROUDACTION}

European sea bass, Dicentrarchus labrax (L., 1758), is a demersal species found throughout the Mediterranean Sea and Eastern North Atlantic from Southern Morocco to the Norwegian littoral (Frtsch et al., 2006).This species is an important species in the Egyptian coasts of Mediterranean Sea especially in Bardawil lagoon and it the main demersal target of hand lines, long lines and trolling fisheries operating. The sea bass, D. labrax is economic species and reaches high prices in the market and are much appreciated nationally. Age 
determination is essential for studies of growth and population biology of fisheries research. Also, the data on age structure can indicate the health of the population, mortality and survival rate (Nikolsky, 1976; Bagenal, 1978 and Rounseefell and Everhart, 1985).

The previous studies on D. labrax in the lagoon indicated that the exploited and fishing effort were above optimum levels (Hegazy \& Sabry, 2001; Salem, 2004; Ameran et al., 2008 and Mehanna et al., 2010). This work was carried out to supplement information about biological aspects and exploitation rates of D. labrax in Bardawil lagoon that could be useful for management of this important species.

\section{AREA OF STUDY}

\section{MATERIALS AND METHODS}

The study was carried out in the Bardawil lagoon (Fig. 1). The lagoon is located in an arid area in the northern part of the Sinai Peninsula Egypt and it covers an area of $693 \mathrm{~km}^{2}$. It separated from the Mediterranean Sea by a long narrow sand-bar measuring $300 \mathrm{~m}$ wide. Tow inlets ( Boughaz) connect the lagoon to the Sea. The lagoon is extremely shallow and the water depth never exceeds $3 \mathrm{~m}$.

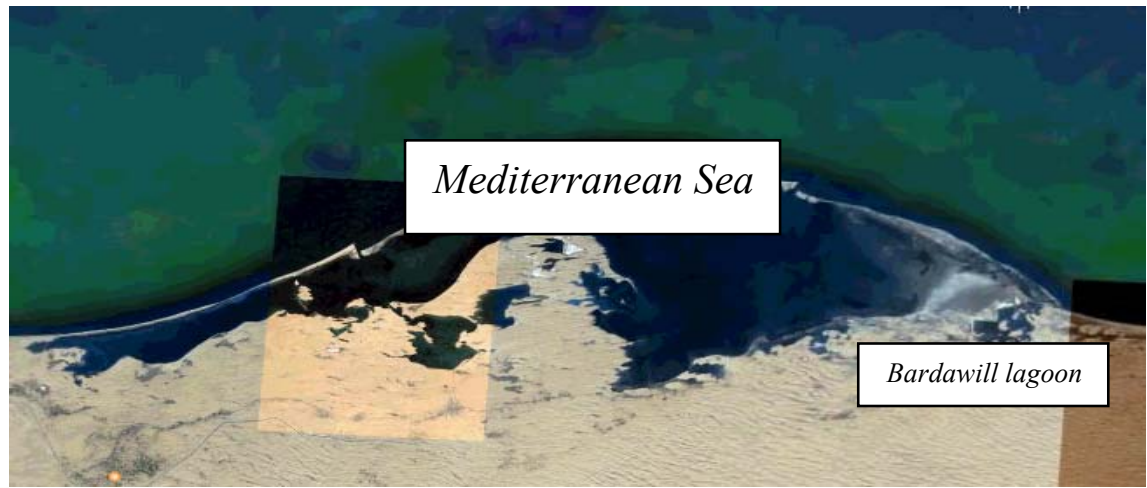

Fig. 1: The Bardawill lagoon

\section{SAMPLING}

Fish samples were collected monthly from commercial hand lines catches between August, 2009 and November, 2010. The boats were equipped with two to four hand line which attached to the boat's side. Each one line is often $5-10 \mathrm{~m}$ long and containing one hook. The hooks are often 2-3 cm long containing life bait. One to three fishermen work on each boat. The fishing boats work in night from a static position. The lines laid at depths ranging from $2-4 \mathrm{~m}$. The total lengths to the mm using a fish measuring board and total weight was recorded to the nearest $0.1 \mathrm{~g}$ were taken for 1688 specimens of D. labrax For age determination, the scales were removed from the left side of each fish behind the tip of the pectoral fin for 586 specimens. In the laboratory, the scales were cleaned and stored dry in envelopes for the subsequent study. Later on, scales 
were soaked overnight in 10\% ammonia solution. 5-7 scales were placed between two glass slides, and examined by a projector with $33 \mathrm{x}$ magnifications. On the clearest scale from each batch, the total scales radius as well as the radius of each annulus were measured to the nearest $0.01 \mathrm{~cm}$.

\section{DATA ANALYSIS}

The back-calculated total length at the end of each year was determined from scale measurements using Lea's, 1910 equation as $\mathrm{L}_{x}=\mathrm{L}_{\mathrm{p}}\left(\mathrm{S}_{\mathrm{x}} / \mathrm{S}_{\mathrm{P}}\right)$, where: $L_{x}$ equals length of fish at age $(x), L_{p}$ equals the fish length at capture, $S_{x}$ equals the scale radius at annulus $x$ and $S_{p}$ equals total scale radius.

The relationship between length and weight was described by the power equation ( $\mathrm{W}=\mathrm{a}^{*} \mathrm{~L}^{\mathrm{b}}$, Ricker, 1975), where $\mathrm{W}$ is the total weight $(\mathrm{g})$, and $\mathrm{L}$ is the total length $(\mathrm{cm}), a$ and $b$ are constants. The calculated weight at the end of each year was estimated by applying length-weight equation.

The von Bertalanffy growth equation (VBGE): $\mathrm{L}_{\mathrm{t}}=\mathrm{L}_{\infty}\left(1-\mathrm{e}^{-\mathrm{k}(\mathrm{t}-\mathrm{t})}\right.$ ) was used to describe growth in size, where $L_{t}$ is the length at age $t, L_{\infty}$ the asymptotic length, $\mathrm{K}$ the body growth coefficient and $\mathrm{t}_{0}$ the hypothetical age at which a fish would have zero length. The values of $\mathrm{L} \infty$ and $\mathrm{K}$ were estimated by plotting $\mathrm{L}_{\mathrm{t}}$ vs $\mathrm{L}_{\mathrm{t}+1}$ using the Ford, 1933 - Walford, 1946 plot, while $\mathrm{t}_{0}$ was estimated by Gulland and Holt plot, 1959. The maximum length $\left(L_{\max }\right)$ was obtained from extreme value theory (Formacion et al., 1991) using the FiSAT program.

The length-converted catch curve method (Pauly, 1984a) was used to estimate the instantaneous rate of total mortality $(Z)$ by using the FiSAT program. The instantaneous rate of natural mortality $(\mathrm{M})$ was obtained by two methods: Ursin (1967) formula as $\mathrm{M}=\mathrm{W}^{-1 / 3}$ where $\mathrm{W}$ is the mean weight of the whole sample and the equations of Pauly, 1980 as $\log \mathrm{M}=\left[-0.0066-0.279 \log \mathrm{L}_{\infty}+0.6543\right.$ $\log \mathrm{K}+0.4634 \log \mathrm{T}]$. The fishing mortality $(\mathrm{F})$ was estimated by subtracting the value of natural mortality from the total mortality as $F=Z-M$, while the exploitation rate $\mathrm{E}=\mathrm{F} / \mathrm{Z}$.

The probability of capture was estimated from length-converted catch curve, using the running average technique to determine $\mathrm{L}_{\mathrm{c}}$ (Pauly, 1984 ).

The model of Beverton and Holt (1966) as modified by Pauly and Soriano (1986) incorporated in FiSAT program (Gayanilo et al., 1997) was used to predict the relative yield-per-recruitment and the relative biomass per recruit as $\mathrm{Y}^{\top} / \mathrm{R}=\mathrm{EU}^{\mathrm{M} / \mathrm{K}}\left[1-(3 \mathrm{U} / 1+\mathrm{m})+\left(3 \mathrm{U}^{2} / 1+2 \mathrm{~m}\right)-\left(\mathrm{U}^{3} / 1+3 \mathrm{~m}\right)\right]$ where, $\mathrm{U}=1-(\mathrm{Lc} /$ $\mathrm{L} \infty), \mathrm{m}=(1-\mathrm{E}) /(\mathrm{M} / \mathrm{K})=(\mathrm{K} / \mathrm{Z}): \mathrm{M}$ is the natural mortality, $\mathrm{K}$ is the body growth coefficient and $\mathrm{E}$ is the exploitation rate. The relative biomass per recruit $\left(\mathrm{B}^{\prime} / \mathrm{R}\right)=\left(\mathrm{Y}^{\prime} / \mathrm{R}\right) / \mathrm{F}$ where, $\left(\mathrm{Y}^{`} / \mathrm{R}\right)$ is the relative yield-per-recruit and $\mathrm{F}$ is the fishing mortality. The optimum exploitation rate which produces maximum yield was found from the yield-per-recruit and biomass-per-recruit model $\left(\mathrm{E}_{\max }\right)$. Also, the exploitation rate at which the marginal increase of $Y^{\prime} / R$ is $0.1\left(E_{0.1}\right)$, and that which reduces the biomass to $50 \%$ of its unexploited level $\left(\mathrm{E}_{0.5}\right)$ were estimated.

\section{RESULTES AND DISSCUTION}




\section{Age and growth}

The observed total length of the investigated D. labrax ranged from 18.2 to $64.7 \mathrm{~cm}$ and the observed total weight varied from 62 to $2823 \mathrm{~g}$. Age determination is essential for studies of growth and population biology of fisheries research. Six age groups were identified for D. labrax. The growth in length and increment from the back calculated length was shown in table (1) and Figure (2)

Table 1: Back - calculation length (TL, cm) at the end of each life different years of $D$. labrax in Bardawill lagoon.

\begin{tabular}{|c|c|c|c|c|c|c|c|c|}
\hline \multirow{2}{*}{$\begin{array}{l}\text { Age } \\
\text { group }\end{array}$} & \multirow{2}{*}{ No. } & \multirow{2}{*}{$\begin{array}{l}\text { Observed } \\
\text { length }\end{array}$} & \multicolumn{6}{|c|}{ Average calculated lengths $(\mathrm{cm})$ at the end of each year $(\mathrm{cm})$} \\
\hline & & & 1 & 2 & 3 & 4 & 5 & 6 \\
\hline 0 & 135 & 22.8 & & & & & & \\
\hline 1 & 383 & 34.6 & $\underline{24.38}$ & & & & & \\
\hline 2 & 39 & 45.6 & 24.00 & $\underline{38.15}$ & & & & \\
\hline 3 & 10 & 52.4 & 23.54 & 37.55 & $\underline{47.86}$ & & & \\
\hline 4 & 8 & 56.5 & 23.35 & 37.14 & 47.42 & $\underline{53.97}$ & & \\
\hline 5 & 6 & 60.2 & 23.30 & 37.14 & 47.47 & 53.85 & 59.09 & \\
\hline 6 & 5 & 63.4 & 23.23 & 37.13 & 47.65 & 54.00 & $\overline{59.03}$ & $\underline{62.88}$ \\
\hline \multicolumn{3}{|c|}{ Average } & 23.63 & 37.42 & 47.60 & 53.94 & 59.06 & 62.88 \\
\hline \multicolumn{3}{|c|}{ Increment } & 23.63 & 13.79 & 10.18 & 6.34 & 5.12 & 3.82 \\
\hline
\end{tabular}

It was obvious from Table (1) that, the dominate of age group one $(65.35 \%)$, while the age grope six the least age group in the catch $(0.8 \%)$. The highest annual increment was occurred during the first year of life, while a noticeable decrease was observed in the second year, reaching its minimal value during the six year of life (Fig. 2). The recorded of life groups of bass in Bardawil lagoon were different from study to another as shown in Table (2).

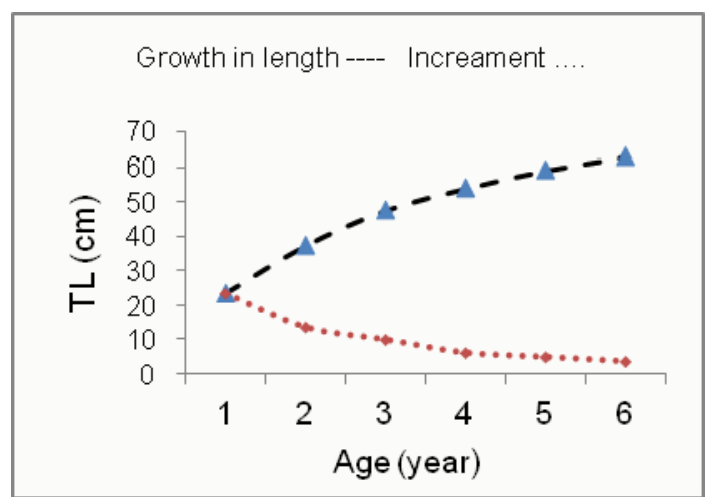

Fig. 2: Growth in length and growth increment of D. labrax in Bardawil lagoon. 
Table 2: The length at the end of life year of D. labrax in Bardawil lagoon given by different authors

\begin{tabular}{|c|c|c|c|c|c|c|c|c|c|c|c|c|}
\hline \multirow{2}{*}{ Region } & & Age & $\mathrm{N}$ & \multicolumn{8}{|c|}{ Total leng th at the end of life year } & \multirow{2}{*}{ Referenes } \\
\hline & $3 e x$ & & 14 & 1 & 2 & 3 & 4 & 5 & 6 & 7 & 8 & \\
\hline Bardawill lagoor, fishirg & $\mathrm{M}$ & $1--2$ & 136 & 22.7 & 276 & & & & & & & Bebars, 1986 \\
\hline $\begin{array}{l}\text { seasor } 1985186 \\
\text { Bardawill lagoon }\end{array}$ & $\begin{array}{l}\mathrm{F} \\
\mathrm{M}+\mathrm{F}\end{array}$ & $\begin{array}{l}1--6 \\
1-7\end{array}$ & 35 & $\begin{array}{l}25.1 \\
16.1\end{array}$ & $\begin{array}{l}41.3 \\
30.8\end{array}$ & $\begin{array}{l}5431 \\
42.5\end{array}$ & $\begin{array}{l}63.6 \\
51.7\end{array}$ & $\begin{array}{l}70.2 \\
59.1\end{array}$ & $\begin{array}{l}74.6 \\
64.9\end{array}$ & 69.6 & & egazy \& Sabry, 2001 \\
\hline $\begin{array}{l}\text { Bardawill fishing season } \\
2000\end{array}$ & $\mathrm{M}+\mathrm{F}$ & $1--4$ & 1463 & 22.6 & 306 & 36.4 & 41.8 & & & & & \\
\hline $\begin{array}{l}\text { fishing season } \\
2001\end{array}$ & $\mathrm{M}+\mathrm{F}$ & $1--5$ & 1204 & 22.4 & 31.3 & 375 & 43 & 47.5 & & & & Salemeta \\
\hline Bardawill lagoon & $\mathrm{M}+\mathrm{F}$ & $1--4$ & --- & 22.5 & 33.4 & 43.45 & 49.5 & & & & & Khalifa, 2005 \\
\hline Bardawill lagoon & $M+F$ & $1--8$ & 1419 & 23.1 & 343 & 466 & 538 & 59.8 & 63.9 & 67.3 & 69.8 & Me harina et al, 2010 \\
\hline Bardawill lagoon & $\mathrm{M}+\mathrm{F}$ & $1--6$ & 1688 & 24.38 & 38.15 & 47.86 & 5397 & 59.09 & 62.88 & & & Fresent study \\
\hline
\end{tabular}

The length - weight relationship (Fig. 3) was described by the power equation as: $\mathrm{W}=0.014 * \mathrm{~L}^{2.883}\left(\mathrm{R}^{2}=0.97\right)$. This result agreed with the previous studies. Length-weight relationship is very important for fisheries biologists, where, the differences in length-weight relationship might be interpreted as being due to differences in growth and morphometry between regions (Barnabè, 1976) and it is a practical index of the condition of fish, and varies over the year according to factors such as food availability, feeding rate, gonad development and spawning period (Bagenal and Tech, 1978). In the present study, the length weight relationship was closed to the previous studies.

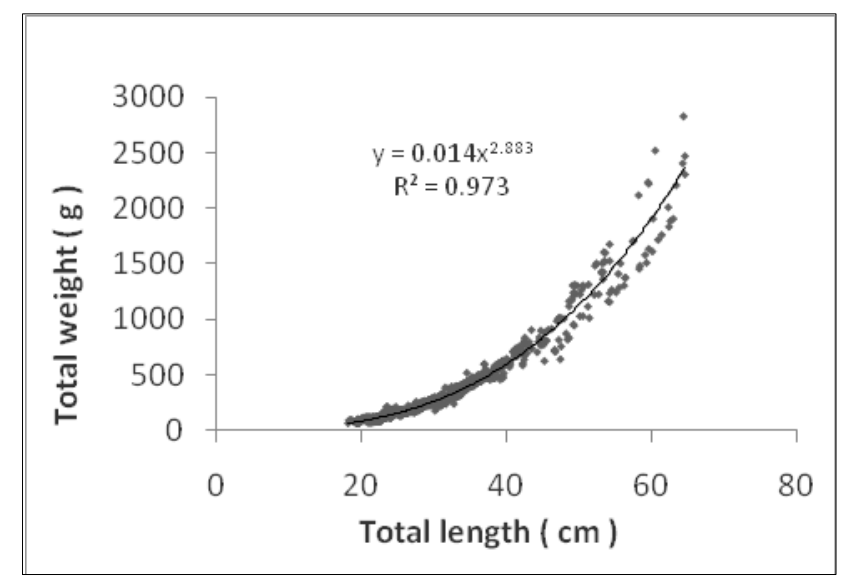

Fig. 3: Length - weight relationship of D. labrax in Bardawil lagoon.

The back-calculation weights at the end of each year of life for D. labrax were estimated by applying the length - weight relationship and the results are given in Table (3). 
Table 3: Back - calculation weight ( $\mathrm{g}$ ) at the end of each life different years of D. labrax in Bardawil lagoon

\begin{tabular}{|c|c|c|c|c|c|c|c|c|}
\hline \multirow{2}{*}{$\begin{array}{l}\text { Age } \\
\text { group }\end{array}$} & \multirow{2}{*}{ No. } & \multirow{2}{*}{$\begin{array}{c}\text { Observed } \\
\text { weight }\end{array}$} & \multicolumn{6}{|c|}{ Average calculated weight $(\mathrm{g})$ at the end of each year } \\
\hline & & & 1 & 2 & 3 & 4 & 5 & 6 \\
\hline o & 135 & 110 & & & & & & \\
\hline 1 & 383 & 357 & $\underline{140}$ & & & & & \\
\hline 2 & 39 & 831 & 133 & $\underline{508}$ & & & & \\
\hline 3 & 10 & 1320 & 126 & 485 & $\underline{976}$ & & & \\
\hline 4 & 8 & 1495 & 123 & 470 & 950 & $\underline{1380}$ & & \\
\hline 5 & 6 & 1720 & 122 & 470 & 953 & 1371 & $\underline{1792}$ & \\
\hline 6 & 5 & 2043 & 121 & 470 & 964 & 1383 & 1787 & $\underline{2144}$ \\
\hline \multicolumn{3}{|c|}{ Average } & 128 & 480 & 961 & 1378 & 1790 & 2144 \\
\hline \multicolumn{3}{|c|}{ Increment } & 128 & 353 & 481 & 417 & 412 & 354 \\
\hline
\end{tabular}

Growth parameters of von Bertalanffy were calculated as $\mathrm{L}_{\infty}=70.82 \mathrm{~cm}$, $\mathrm{K}=0.35$ year $^{-1}$ and $\mathrm{t}_{0}=-0.217$ year and the obtained equation was $L_{t}=$ $70.82 *\left(1-e^{-0.35(t+0.217)}\right)$. The decrease in $L \infty$ values can be attributed to disappearance of the largest fish sizes from the catch. Parsons (1982) found that, the older year classes were related to the higher $L \infty$ value for the same species. In the present study, the maximum observed length $64.5 \mathrm{~cm}$. Approximately $85 \%$ of the investigated fishes were less than $36 \mathrm{~cm}$, (the minimum landing size for D. labrax) would satisfy the management objective of reducing growthoverfishing (Pawson et al., 2005). In the same sense, the body growth coefficient $\left(\mathrm{K}=0.35 \mathrm{yr}^{-1}\right)$ was higher than that of most of the previous studies. LopezMartinez et al. (2003) mentioned that the absence of small size in the samples causes an underestimated value for the growth coefficient. Also, individuals during the first years grow faster (Dominguez-Seoane et al., 2006). Mcllwain et al.(2005) mentioned that the differences in growth parameters due to age, sex, maturity and sampling period for the same species. The constant of lengthweight relationship and growth parameters for D. labrax in Bardawil lagoon were summarized in Table (4).

The predicted extreme lengths $\left(L_{\max }\right)$ of D. labrax were $70.05 \mathrm{~cm}$, respectively (Fig. 4). Maximum length to the asymptotic length $\left(\mathrm{L}_{\max } / \mathrm{L} \infty=\right.$ 0.98 ) is an important parameter of the life history as a recorded by Stergiou (2000) who found that the mean value of $L_{\max } / L_{\infty}$ for marine fish is 0.90 . The present value of $L_{\max } / L_{\infty}$ was much closed to the mean value. 
Table 4: Constants of length weight relationship and the growth parameters of D. labrax in Bardawil lagoon.

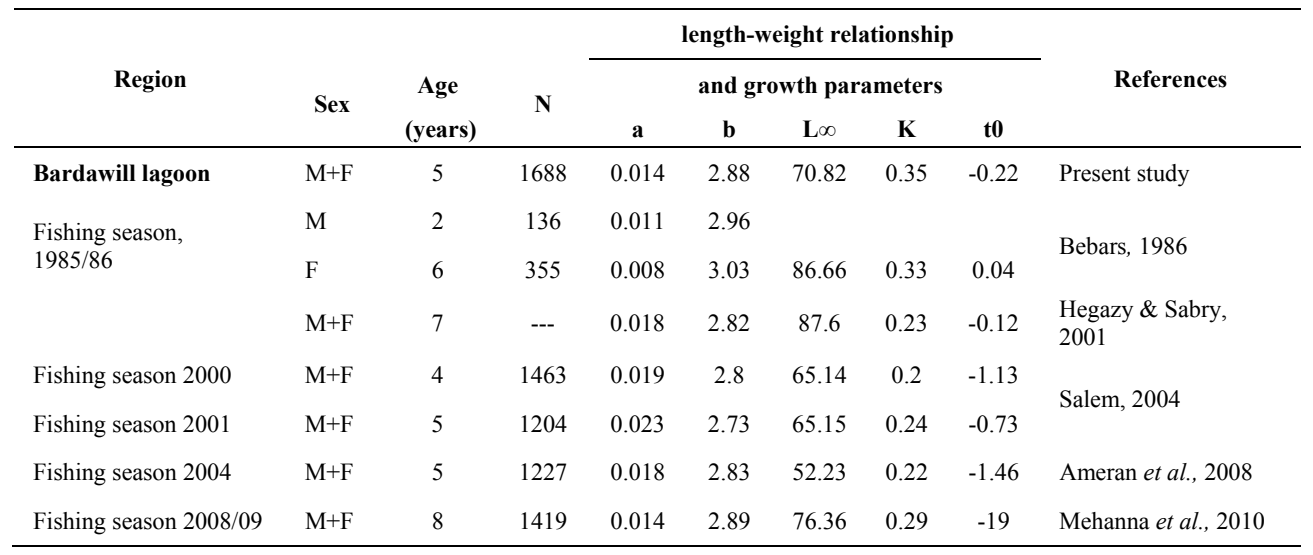

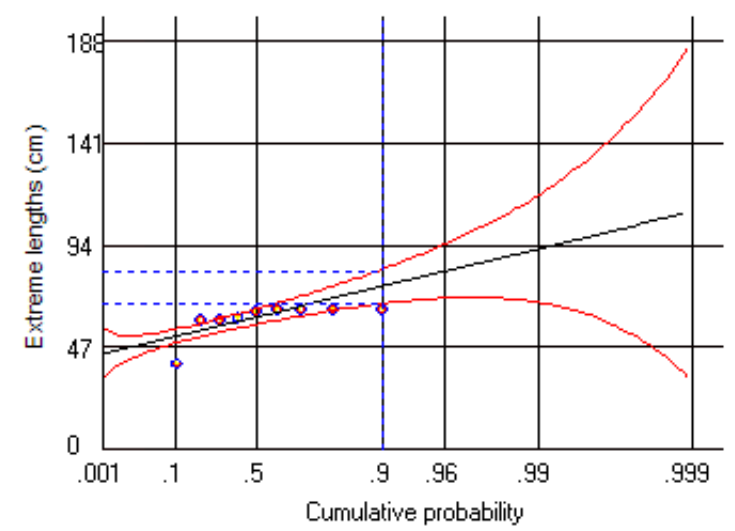

Fig. 4: Observed and prediction of the maximum length of D. labrax in Bardawil lagoon $\left(L_{\max }=70.05 \mathrm{~cm}\right)$.

\section{Mortalities and exploitation rate}

The total mortality $(Z)$ from length-converted catch curves was estimated as $1.03 \mathrm{yr}^{-1}$ (Fig. 5), while the natural mortality (M) was estimated as $0.39 \mathrm{yr}^{-1}$ and the fishing mortality rate $(F)$ was 0.64 year $^{-1}$. From these results, the exploitation rate $(\mathrm{E})$ was 0.623 . The current exploitation rate $(E=0.623)$ indicates that the stock of sea bass was heavily exploited according to Gulland (1971) who suggested that the optimum exploitation rate for any fish stock is about 0.5 at $\mathrm{F}=\mathrm{M}$ and more recent, Pauly, 1987 proposed a lower optimum $\mathrm{F}$ that equal to $0.4 \mathrm{M}$, so the values of fishing mortality and exploitation rate were relatively high indicating a high level exploitation. 


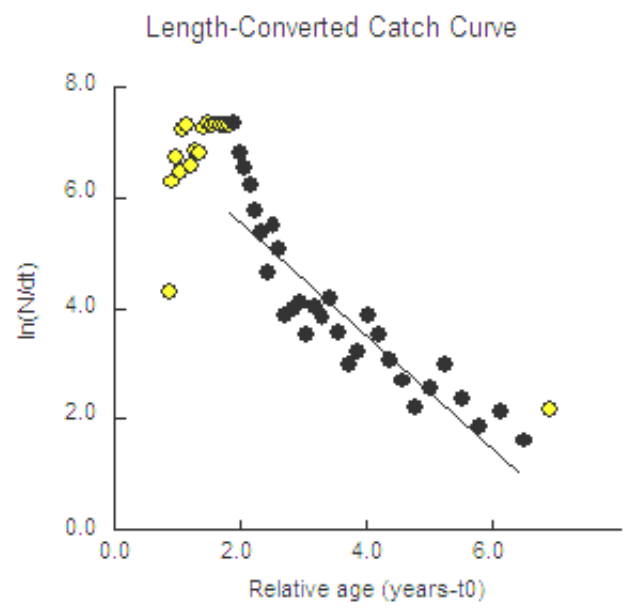

Fig. 5: length-converted catch curve of D. labrax in Bardawil lagoon.

The probability of capture is given in Figure (6) using the running average technique, where $25 \%$ of all fish were caught at $18.63 \mathrm{~cm} \mathrm{TL,} 50 \%$ at $20.16 \mathrm{~cm}$ TL (the length at first capture, $\mathrm{L}_{\mathrm{c}}$ ) and $75 \%$ at $21.75 \mathrm{~cm}$ TL. The length at first capture is an important input in the computation of the yield per recruit and relative biomass per recruit, where the Knife Edge selection procedure assumes that fishes less than length at first capture are not captured by the fishing gear. The length at first capture in this study was considerably smaller compared with the first sexual maturity of bass $\left(L_{m} 31.6 \mathrm{~cm} \mathrm{Lt}\right)$ as recorded by Ameran et al. (2008).

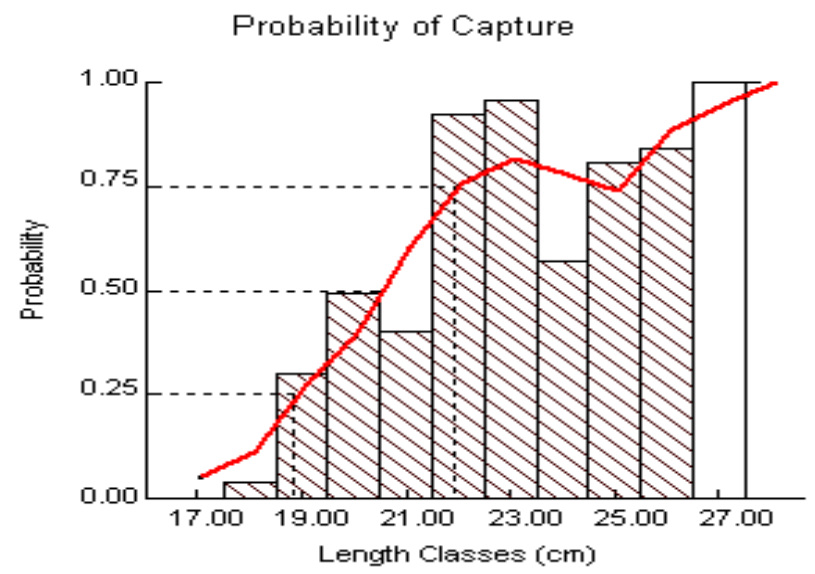

Fig. 6: Analysis of capture probability for D. labrax in Bardawil lagoon. 


\section{The seasonal recruitment}

The structure of recruitment patterns of D. labrax in the Bardawil lagoon indicates normal recruitment groups distributed annually. The annual recruitment pattern consists of one cohort produced per year with the highest peak of fish occurring at June, $27.25 \%$ of the observed recruitment (Fig. 7).

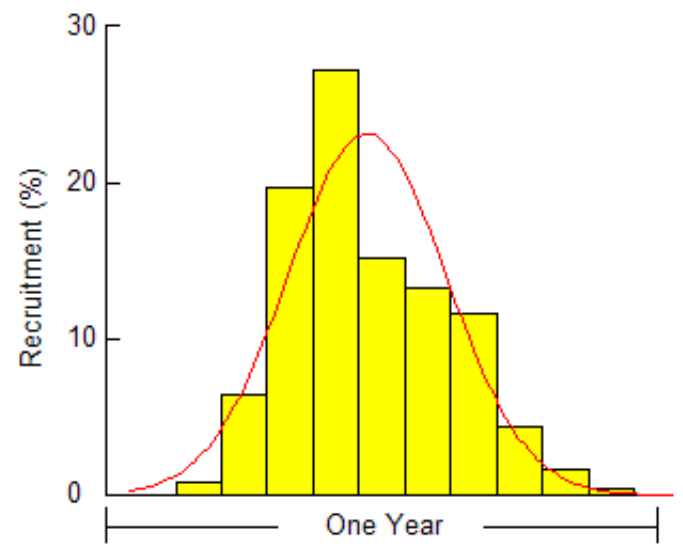

Fig. 7: Recruitment pattern of D. labrax in Bardawil lagoon.

\subsection{The relative yield-per-recruit $\left(Y^{\prime} / R\right)$ and biomass per-recruit $(B / R)$}

The Knife Edge selection procedure (Fig. 8) showed the relative yieldper-recruit $\left(\mathrm{Y}^{\prime} / \mathrm{R}\right)$ and biomass per-recruit $(\mathrm{B} / \mathrm{R})$ of $D$. labrax vs. the exploitation rate in Bardawil lagoon. The maximum and economic increase of $\mathrm{Y}^{\prime} / \mathrm{R}$ at the exploitation rates was $0.5\left(E_{\max }\right)$ and $0.42\left(E_{0.10}\right)$. The exploitation rate which reduces the biomass to $50 \%$ of its unexploited one $\left(E_{0.5}\right)$ was 0.31 . Therefore, the current exploitation rate is higher than the predicted exploitation rates at the maximum economic yield, $(M E Y)$, the maximum sustainable yield, $(M S Y)$ and maintains $50 \%$ of stock. From that results, the stock of bass in Bardawil lagoon is a heavily exploitated. Therefore the current exploitation rate should be reduced $32 \%$ (from 0.62 to 0.42 ) and $50 \%$ (from 0.62 to 0.31 ) to obtain the maximum economic yield, $(M E Y)$ and the exploitation rate which reduces the biomass to $50 \%$, respectively. Also, the results indicated that an increase of $L_{c}$ to the first sexual maturity $\left(32 \mathrm{~cm}\right.$ as $\left.L_{t}\right)$ would be associated with an increase of $Y^{\prime} / \mathrm{R}$ by $17 \%$ (Fig. 9). Thus, for management purpose, the current exploitation rate must be reduced from 0.62 to $0.31(50 \%)$ or the present length at first capture $\left(L_{c}\right)$ should be increased from 20.16 to $32 \mathrm{~cm}$ at the current the exploitation rate. 


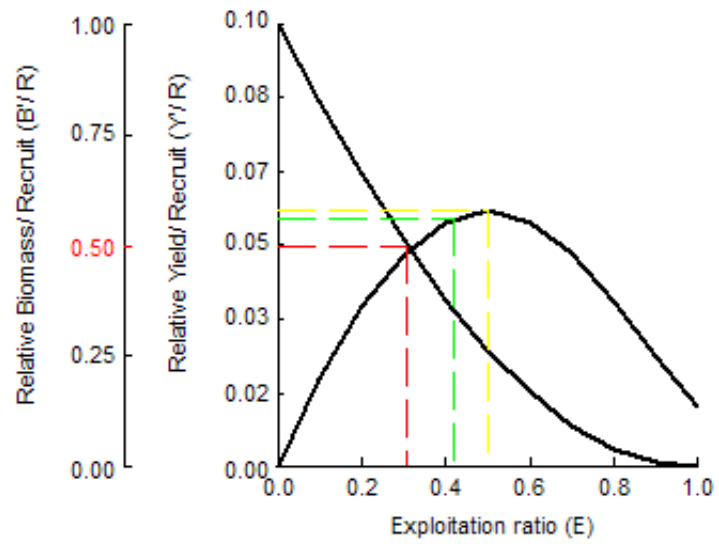

Fig. 8: The relative yield-per-recruit $\left(\mathrm{Y}^{\prime} / \mathrm{R}\right)$ and biomass per-recruit $(\mathrm{B} / \mathrm{R})$ D. labrax in Bardawill lagoon with $\mathrm{Lc}$ is $20.16 \mathrm{~cm}$ as $L t$.

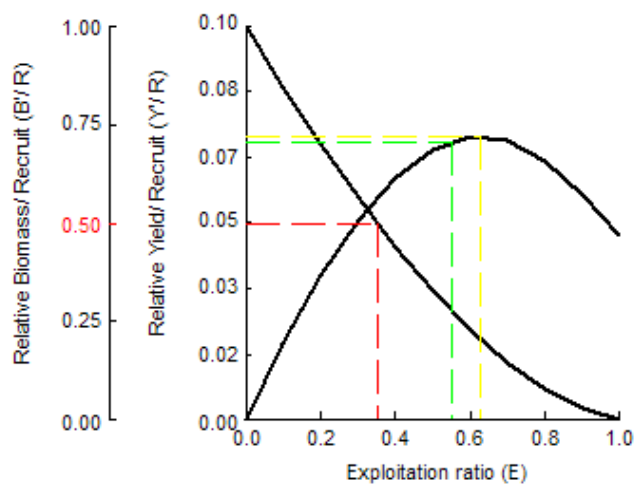

Fig. 9: The relative yield-per-recruit $\left(\mathrm{Y}^{\prime} / \mathrm{R}\right)$ and biomass per-recruit $(\mathrm{B} / \mathrm{R})$ D. labrax in Bardawill lagoon with $\mathrm{Lc}$ is $32 \mathrm{~cm}$ as $L t$.

\section{REFERENCES}

Ameran, M.; Salem, M.; El-Aiatt, A. (2008). Age, growth and mortality of the sea bass, Dicentrarachus labrax from the Bardawil lagoon, North Sinai, Egypt. Conference. Sharm El-Shek. April, 13 - 16, 2008, Egypt. (J. Egypt. Acad. Soci. Environ. Develop, 9 (2):1110-8770.

Bagenal, T. (1978). Methods for Assessment of Fish Production in Freshwaters. Blackwell Scientific Publications, Oxford, pp. 1-365. 
Bagenal, T.B. and Tesch, F.W. (1978). Age and growth. In: T. Bagenal, Editor, Methods for Assessment of Fish Production in Fresh Waters. IBP Handbook No. 3 (3rd ed.), Blackwell Scientific Publications, Oxford (1978), pp. 101-136 (Chapter 5).

Barnabe, G. (1976). Methods for assessment of fish production (eggs and early life history) 166-199. Blackwell Sc. pub1., oxford and Edinburg.

Bebars, M. I. (1986). Second scientific report on the stock assessment management of the Bardawil lake fisheries submitted to the Academy of Scientific Research and Technology, December 1986.

Bertalanffy, L. von (1934). A quantitative theory of organic growth (Inquiries on growth Laws. 2). Hum. Biol., 10: 181-213.

Beverton, R. J. H. and Holt, S. J. (1966). A review of methods for estimating mortality rates in exploited fish populations, with special reference to sources of bias in catch sampling. Rapp. P. V. Reun. CIEM, 140(1): 67-83.

Domínguez-Seoane, R.; Pajuelo, J. G.; Lorenzo, M. J.; Ramos G. A. (2006). Age and growth of the sharpsnout seabream Diplodus puntazzo (Cetti, 1777) inhabiting the Canarian archipelago, estimated by reading otoliths and by backcalculation. Fish. Res., 81(2-3): 142-148.

Ford, E., 1933. An account of the herring investigation conducted at Plymouth. J. Marin. Biol. Ass. U.K., $19: 305$ - 384.

Formacion, S. P.; Rongo, J. M.; and Sambilay, V. C. (1991). Extreme value theory applied to the statistical distribution of the largest lengths of fish. Asian Fish. Sci. 4:123-135.

Fritsch, M.; Morizur, Y.; Lambert, E.; Bonhomme, F. and Guinand, B. (2006). Assessment of sea bass (Dicentrarchus labrax, L.) stock delimitation in the Bay of Biscay and the English Channel based on mark-recapture and genetic data, 83: 123-132

Gayanilo,F. C.; Sparre, P. and Pauly, D. (1997). FAO-ICLARM stock assessment tools. Reference manual.ICLARM International Center for Living Aquatic Resources Management Food and Agricultural Organisation of the United Nation. Rome., PP 262.

Gulland, J. A. (1971). The fish resources of the Ocean, Fishing News Books, Ltd., West Byfleet, UK, 255 pp. 
Gulland, J. A. and Holt S. L. (1959). Estimation of growth parameters for data at unequal time intervals. J. Cons. Perm. Int. Explor. Mer., 25 (1): 47 - 49.

Hegazy, M. R.; Sabry, E. A. (2001). Stock assessment for the sea bass (Dicentrachus labrax, L, 1758) Piscs: Moronidae in Bardawil lagoon Egypt. Vert. Anat. \& Embr, 34: 41-55.

Khalifa, U. S. (2005). Population characteristics and fisheries management of European sea bass, Dicentrachus labrax L., in Bardawil lagoon, Egypt. Afr. J. Biol. Sci., (1): 69-78.

Lea, E., 1910. On the methods used in the herring investigations. Publ. Circonstance, Cons. Int. Explor. Mer., 53: 7-174.

López-Martínez，J.; Arreguín-Sánchez，F.; Hernández-Vázquez，D.; GarcíaJuárez, A.R.; Valenzuela-Quiñones, W. (2003). Interannual variation of growth of the brown shrimp Farfantepenaeus californiensis and its relation to temperature. Fish. Res. 61: 95-105.

Mcllwain, J. L.; M. R. Claereboudt; H. S. AL-Oufi; S. Zaki and, G.S. Goddard (2005). Spatial variation in age and growth of the Kingfish (Scomberomorus commerson) in the coastal waters of The Sultanate of Oman. Fish. Res., 73: $283-298$.

Mehanna, S., F.; El-Aiatt, A.; Ameran, M. and Salem, M. (2010). Population dynamic and fisheries regulation for the European sea bass Dicentrarchus labrax (Moronidae) at Bardawil lagoon, Egypt. The 3rd Global Fisheries $\&$ Aquaculture Research Conference, 29 Nov. to 1 Dece. 2010, Cairo.

Nikolsky, G.V. (1976). The Ecology of Fishes. Academic Press, London, pp. 3-352.

Parsons, C. (1982). Biology of bass Dicentrachus labrax (L) from South -west Wales, part II hanours project, Univ. of Wales, pp 66

Pawson, M.G.; Pickett, G.D. and Smith, M.T. (2005). The role of technical measures in the recovery of the UK sea bass (Dicentrarchus labrax) fishery 1980-2002. Fish. Res. 76: 91-105.

Pauly, D. and Soriano, M. L. (1986). Some practical extensions to Beverton and Holt relative yield-per-recruit model in Maclean,J.L.,Dizon, L.B.,Hosillo,L.V.(Eds.) ,the First Asian Fisheries Forum .Asian Fisheries Society,Manila,Philippines,.491-496. 
Pauly, D. (1980). On the interrelationships between natural mortality, growth parameters, and mean environmental temperature in 175 fish stocks. J. Cons. Int. Explor. Mer., 39: 175-192.

Pauly, D. (1984a). Length-converted catch curves: a powerful tool for fisheries research in the tropics (Part II). ICLARM Fishbyte. 2(1): 17-19.

Pauly, D. $\left(1984_{b}\right)$. Fish population dynamic in tropical water: A manual for use with programmable calculators. ICLARM Stud. Rev. (8): 325p.

Pauly, D. (1987). A review of the system for analysis of length in fish and invertebrates. In: Pauly, D., Morgan, G. R. (Eds.), Length-based Methods in Fisheries Research. Proceedings of the $13^{\text {th }}$ ICLARM Conference, Manila, Philippines, p. 7-34.

Pawson, M.G.; Pickett, G.D. and Smith, M.T. (2005). The role of technical measures in the recovery of the UK sea bass, Dicentrarchus labrax fishery 1980-2002. Fish. Res., 76: 91-105.

Ricker, W.E. (1975). Computation and interpretation of biological statistics of fish populations. Bull. Fish. Res. Board Can., 191: p. 382

Rounseefell, G.A. and Everhart, W.H. (1985). Fishery Science, Its Methods and Applications. International Books and Periodicals Supply Service, New Delhi, pp. 1- 444.

Salem, M. (2004). Biological studies for the fishery regulations and management of the Bardawil lagoon. Ph.D. thesis, Fac. Envi. Agri. Sci. Suez Canal Univ, Egypt.

Stergiou, K. I. (2000). Life- history patterns of fishes in the Hellinc Sea. Web. Ecol. 1:1-10

Ursin, E. (1967). A mathematical model of some aspects of fish growth, respiration and mortality. J. Fish. Res. Bd. Can., 24: 2355-2453.

Walford, L. A. (1946). A new graphic method of describing the growth of animals. Mar. Biol . Bull. 90(2):141-147. 